\title{
ANALISIS FAKTOR-FAKTOR YANG MEMPENGARUHI DI VIDEND PAYOUT RATIO PADA PERUSAHAAN YANG GO PUBLICDI INDONESIA
}

\author{
Oleh: Sri Hermuningsih \\ (Staf Pengajar J urusan Ekonomi/ Manajemen Perusahaan FE UST Yogyakarta)
}

\begin{abstract}
Abstrak
Pembayaran dividend pada perusahaan yang Go Public mempunyai dampak yang sangat penting baik bagi para investor maupun bagi perusahaan yang akan membayarkan dividennya, karena kebijakan dividend adalah sangat penting untuk memenuhi harapan para pemegang saham terhadap dividend dan di satu sisi juga tidak harus menghambat pertumbuhan perusahaan.Dalam pelaksanaan Kebijakan dividend suatu perusahaan akan melibatkan du pihak yan berkepentingan dan saling bertentangan, yaitu kepentingan para pemegang saham dengan dividennya dan kepentingan perusahaan dengan laba ditahannya.

Tujuan yang ingin dicapai dalam penelitian ini adalah 1).Untuk mengetahui Model yang paling fit hubungan dan pengaruh secara simultan atas variabelvariabel : Assets (diwakili posisi kas/cash position $=X 1$, potensi pertumbuhan/growth potential $=X 2$, ukuran perusahaan/firm size $=X 3$, perbandingan antara kewajiban dengan modal/debt to equity ratio $=X 4)$; Equity (diwakili ukuran perusahaan/firm size $=X 3$, dan X6 kepemilikan/Holding; Earnings (diwakili keuntungan/profitability $=X 5$ ), kepemilikan (holding $=X 6$ ) terhadap dividend payout ratio (DPR), 2). Untuk mengetahui pengaruh assets, equity dan earnings secara bersama-sama (simultan) terhadap dividend payout ratio .3). mengetahui pengaruh assets, equity dan earnings secara sendiri-sendiri (partial) terhadap devidend payout ratio.Pengujian dilakukan dengan menggunakan Regresi Bertahap atau Multistage Regression dan Analisis J alur ( Path Analysis).

Hasil penelitian diperoleh kesimpulan bahwa dari 6 (enam) variasbel yang diperkirakan mempunyai pengaruh tidak langsung terhadap Dividend Payout Ratio ternyata hanya 2 (dua) variabel yang berpengaruh, yaitu Variabel ukuran perusahaan $/$ firm size $=X 3$ dan variabel Debt to equity ratio $=X 4$ melalui variabel intervening atau variable antara Equity ( Y2). Sedangkan Variabel Pertumbuhan (X2) mempunyai pengaruh signifikan tethadap Assets (Y1), tetapi Assets pengaruhnya tidak signifikan terhadap DPR (Y). Demikian pula Variabel Profit (X5) mempunyai pengaruh yang signifikan terhadap Earning (Y3), tetapi Earning pengaruhnya tidak signifikan terhadap DPR (Y). Hal ini disebabkan karena banyak faktor yang mempengaruhi kebijakan dividend dalam suatu perusahaan dan banyak faktor tersebut saling berinteraksi (terjadi interdependensi) satu sama lain dan juga antara satu jenis perusahaan dengan perusahaan lain juga ada perbedaan-perbedaan pertimbangan. Oleh karena itu sulit untuk memperoleh suatu model yang secara general mampu menjelaskan perilaku perusahaan dalam kebijakan dividend payout ratio.
\end{abstract}

Key Word: Assets, Equity, Earnings, Devidend payout ratio 


\section{A. Pendahuluan}

Kebijakan dan pembayaran dividend pada perusahaan yang go public mempunyai dampak yang sangat penting baik bagi para investor maupun bagi perusahaan yang akan membayarkan dividennya. Pada umumnya para investor mempunyai tujuan utama untuk meningkatkan kesejahteraannya yaitu dengan mengharapkan return dalam bentuk dividend maupun capital gain. Di lain pihak, perusahaan juga mengharapkan adanya pertumbuhan secara terus-menerus untuk mempertahankan kelangsungan hidupnya, dan sekaligus juga harus memberikan kesejahteraan yang lebih besar kepada para pemegang sahamnya. Tentunya hal ini menjadi unik, karena di satu sisi kebijakan dividend adalah sangat penting untuk memenuhi harapan para pemegang saham terhadap dividend dan di sisi lain bagaimana kebijakan dividend ini bisa dilakukan tanpa harus menghambat pertumbuhan perusahaan.

Pada umumnya para investor yang tidak bersedia mengambil risiko (risk aversion) mempunyai pandangan bahwa semakin tinggi tingkat risiko suatu perusahaan, akan semakin tinggi juga tingkat keuntungan yang diharapkan sebagai hasil atau imbalan terhadap risiko tersebut. Selanjutnya dividend yang diterima pada saat ini akan mempunyai nilai yang lebih tinggi daripada capital gain yang akan diterima di masa yang akan datang. Dengan demikian investor yang tidak bersedia berspekulasi akan lebih menyukai dividend dari pada capital gain.

Dalam pelaksanaannya kebijakan dividend suatu perusahaan akan melibatkan dua pihak yang berkepentingan dan saling bertentangan, yaitu kepentingan para pemegang saham dengan dividennya, dan kepentingan perusahaan dengan laba ditahannya. Di samping itu juga kepentingan bondholder yang dapat mempengaruhi besarnya dividend kas yang dibayarkan. Dividend yang dibayarkan kepada para pemegang saham tergantung kepada kebijakan masingmasing perusahaan, sehingga memerlukan pertimbangan yang lebih serius dari manajemen perusahaan. Kebijakan dividend atau keputusan dividend pada hakikatnya adalah menentukan porsi keuntungan yang akan dibagikan kepada pemegang saham dan yang akan ditahan sebagai bagian dari laba ditahan (Levy dan Sarnat, 1990).

\section{B. Perumusan Masalah}

Berdasarkan uraian tersebut di atas, maka rumusan masalah dalam penelitian ini adalah sebagai berikut: 
1. Bagaimana model yang paling fit atau yang paling tepat untuk merumuskan hubungan dan pengaruh secara simultan atas variabel-variabel: Assets (diwakili posisi kas/cash position $=\mathrm{X} 1$, potensi pertumbuhan $/$ growth potential=X2, ukuran perusahaan/firm size $=\mathrm{X} 3$, perbandingan antara kewajiban dengan modal/debt to equity ratio $=\mathrm{X} 4$ ); Equity (ukuran perusahaan/firm size $=\mathrm{X} 3$, debt to equity ratio $=\mathrm{X} 4$ dan kepemilikan/Holding $=\mathrm{X6}$ ); Earnings (keuntungan/ profitability=X5, kepemilikan/holding $=\mathrm{X} 6$ ) terhadap kebijakan dividend payout ratio (DPR) pada perusahaan yang go public di Bursa Efek Jakarta?

2. Adakah pengaruh assets, equity dan earnings secara bersama-sama (simultan) terhadap kebijakan dividend payout ratio (DPR) pada perusahaan yang go public di Bursa Efek Jakarta?

3. Adakah pengaruh assets, equity dan earnings secara sendiri-sendiri (partial) terhadap kebijakan devidend payout ratio (DPR) pada perusahaan yang go public di Bursa Efek Jakarta?

\section{Kerangka Dasar Teori}

\section{Teori Dividen}

Dividen merupakan bagian dari keuntungan perusahaan yang didistribusikan kepada para pemegang saham dan pada umumnya dapat dilakukan secara berkala baik dalam bentuk uang (Cash), dividen saham (Stock Dividend), dan dividen ekstra. Dividen ekstra diberikan sebagai tambahan pembayaran dividen pada pemegang saham karena adanya kelebihan harga yang diperoleh perusahaan dari yang diprediksikan. Dividen ekstra biasanya diberikan oleh perusahaan yang menganut kebijakan dividen kecil yang teratur.

Kebijakan dividen adalah keputusan manajemen apakah laba yang diperoleh perusahaan akan dibagikan kepada pemegang saham sebagai dividen atau akan ditahan dalam bentuk laba yang ditahan guna pembiayaan investasi di masa yang akan datang. Total sumber dana intern (internal financing) akan berkurang apabila suatu perusahaan memilih untuk membagi laba sebagai dividen. Kemampuan membentuk dana intern akan semakin besar jika perusahaan lebih banyak menahan laba yang diperoleh.

Kebijakan terhadap pembayaran dividen merupakan keputusan yang sangat penting dalam suatu perusahaan. Kebijakan ini akan melibatkan dua pihak yang mempunyai kepentingan yang berbeda, yaitu pihak pertama para pemegang saham, dan pihak kedua perusahaan itu sendiri. Dividen diartikan sebagai pembayaran kepada para pemegang saham oleh pihak perusahaan dengan keuntungan yang diperoleh. Kebijakan dividen adalah kebijaksanaan yang berhubungan dengan 
pembayaran deviden oleh pihak perusahaan, berupa penentuan besarnya pembayaran dividen dan besarnya laba ditahan untuk kepentingan pihak perusahaan.

Jika manajemen meningkatkan porsi laba perlembar saham yang dibayarkan sebagai dividen, maka mereka dapat meningkatkan kesejahteraan para pemegang saham. Hal ini menyarankan bahwa keputusan dividen yaitu jumlah dividend yang dibayarkan merupakan suatu hal yang sangat penting (Alexander et al., 1993). Dalam banyak hal dividen sering diperlakukan sebagai pertimbangan terakhir setelah pertimbangan investasi dan pertimbangan pembiayaan lainnya, sehingga timbul the residual theory of dividend. Di samping itu ada juga yang mempertimbangkan pembagian dividend kas untuk mengurangi masalah keagenan, sehingga timbul peranan dividen dalam mengurangi masalah keagenan (agency problems), dan masih banyak lagi pertimbangan manajemen dalam menentukan besarnya dividen yang akan dibagikan. Namun demikian tak satupun dari pemikiran ini menghasilkan suatu keputusan yang paling memuaskan, karena secara bersama-sama mereka nampak hanya memberikan penjelasan mengapa perusahaan membayar dividen.

Chang dan Rhee (1990) melakukan studi pengaruh pajak pribadi terhadap kebijakan dividend perusahaan dan pembuatan keputusan struktur modal. Dalam studi tersebut mereka menunjukkan bahwa besarnya rasio pembayaran dividend dipengaruhi oleh perubahan pajak pribadi dalam setiap periode. Dengan pilihan beberapa faktor yang diduga berpengaruh terhadap rasio pembayaran dividend, yaitu potensi pertumbuhan (growth potentia), variabilitas laba, nondebt tax shield, size perusahaan, dan profitabilitas. Hasil studinya menunjukkan bahwa secara keseluruhan periode potensi pertumbuhan dan variabilitas laba berpengaruh negatif terhadap rasio pembayaran dividend. Selanjutnya nondebt tax shield, size perusahaan, dan profitabilitas berpengaruh positif signifikan terhadap rasio pembayaran dividend

Kebijakan dividen bukan hanya mementukan besarnya dividen yang akan dibagikan, tetapi juga mencakup apa bentuk dividen yang akan dibayarkan. Alternatif kebijakan pemberian dividen yang bisa dilakukan oleh perusahaan antara lain: cash dividend, stock dividend, stock split dan repurchase stock.

Cash dividend adalah dividen yang dibayarkan dalam bentuk kas oleh perusahaan kepada pemegang saham. Dividend yield adalah dividen yang dibagikan dalam satu tahun terakhir dibagi harga saham pada saat itu. Persentase dari laba yang dibagikan sebagai cash dividend atau disebut dividend payout ratio. Payout ratio diperoleh dari jumlah dividen per lembar saham dibagi earning perlembar saham. Tingginya dividend payout ratio yang ditetapkan oleh suatu perusahaan 
mengakibatkan semakin kecil dana yang tersedia untuk ditanamkan kembali di dalam perusahaan.

\section{Faktor-faktor yang Mempengaruhi Kebijaksanaan Dividen}

Keuntungan yang diperoleh perusahaan dalam setiap periodenya akan didistribusikan kepada para pemegang saham, dan sebagian lagi akan ditahan untuk diinvestasikan lagi dalam bentuk yang lebih menguntungkan. Oleh karena itu manajemen harus dapat membuat suatu keputusan tentang besarnya keuntungann yang harus dibagikan kepada para pemegang saham, dan berapa yang harus ditahan untuk mendanai perkembangan atau pertumbuhan demi kelangsungan hidup perusahaannya. Keputusan ini akan mempunyai pengaruh yang menentukan terhadap nilai perusahaan..

Menurut Levy dan Sarnat (1970) dan Van Horn (1986), faktor-faktor yang mempengaruhi keputusan dividend adalah meliputi: (1) peraturan atau perundangan, (2) posisi likuiditas, (3) kebutuhan dana untuk melunasi hutang, (4) larangan dalam perjanjian hutang, (5) tingkat ekspansi perusahaan, (6) tingkat keuntungan perusahaan, (7) stabilitas perusahaan, (8) kemampuan memasuki pasar modal, (9) pelaku kelompok pengendali, (10) posisi pemegang sahan sebagai wajib pajak, (11) pajak atas keuntungan yang dilakukan secara salah,dan (12) tingkat inflasi.

Setyawan (1995) mengelompokkan berbagai faktor yang mempengaruhi kebijakan dividend menjadi dua faktor, yaitu faktor intern dan faktor ekstern. Faktor intern adalah faktor yang berpengaruh terhadap kebijakan dividend yang berasal dari dalam perusahaan, misalnya: likuiditas perusahaan, tingkat laba, kemampuan untuk meminjam, dan sebagainya. Dari pengaruh intern ini perusahaan dapat mempengaruhi dan mengendalikan secara aktif sehingga akibatnya dapat dirasakan secara langsung. Faktor ekstern yang merupakan pengaruh yang berasal dari luar perusahaan, misalnya: pajak atas dividend, pajak atas capital gain, akses ke pasar modal, perundangan dan sebagainya. Dari pengaruh faktor ekstern ini perusahaan harus berusaha untuk menyesuaikan karena sulit untuk mengendalikannya.

Banyak sekali faktor yang diperkirakan dapat mempengaruhi kebijakan dividen dalam suatu perusahaan, dalam penelitian ini faktor-faktor yang diperkirakan mempengaruhi kebijaksanaan dividen suatu perusahaan sebagai berikut:

$\mathrm{X}_{1}=$ Posisi kas ( Cash Position)

$\mathrm{X}_{2}=$ Potensi pertumbuhan (Growth potentia)

$\mathrm{X}_{3}=$ Size perusahaan ( firm Size)

$\mathrm{X}_{4}=$ Rasio hutang dan modal (debt to equity ratio)

$\mathrm{X}_{5}=$ Profitabilitas (profitability)

$\mathrm{X}_{6}=$ Holding 
Ke enam diperlakukan sebagai variabel bebas (independent variable) dalam model analisis regresi pertama. Faktor-faktor di atas sebenarnya juga merupakan proksi dari variabel-varibel seperti: Asset (Y1); Equity (Y2) dan Earning (Y3). Oleh karena itu dalam model ini variabel Asset (Y1), Equity (Y2) dan Earning (Y3) dijadikan variabel terikat (dependent variable).

Pada model analisis regresi yang ke dua, variabel Asset (Y1); Equity (Y2) dan Earning (Y3) dijadikan sebagai variabel bebas (independent variable) sedangkan variabel Dividend Payout Ratio/DPR (Y) dijadikan sebagai varibel terikat (dependent variable).

\section{Dividend perlembar dan variabel yang mempengaruhi}

Dalam menentukan kebijakan dividend, manajemen harus memperhatikan kesejahteraan para pemegang saham, di samping harus menjaga pertumbuhan perusahaan dan mempertahankan kelangsungan hidupnya. Menurut Brennan dan Thakor (1990) keputusan yang menciptakan keseimbangan di antara dividend saat ini dan pertumbuhan di masa yang akan datang sehingga memaksimumkan harga saham, disebut dengan kebijakan dividend yang optimal.

Alli at al., (1993) membedakan variabel-variabel yang mempengaruhi pembayaran dividend adalah:

a. Legal Restriction: adalah pertaruran tertentu yang akan membatasi besarnya dividen yang akan dibayar

b. Liquidity Position: Keuntungan yang diperoleh dan laba ditahan yang tinggi tidak harus menyebabkan posisi kas yang tinggi juga, karena adanya kemungkinan bahwa keuntungan dan laba ditahan tersebut telah digunakan untuk membayar hutang, atau melekat pada aktiva selain kas.

c. Absence or lack of other sources of fianancing: Bagi perusahaan yang baru sumber dana intern mempunyai arti yang sangat penting. Hal ini disebabkan karena perusahaan tersebut mengalami kesulitan untuk memperoleh pinjaman atau menjual sahamnya. Sebagai konsekwensinya, dividend yang akan dibayarkan cenderung rendah atau bahkan tidak membagi dividend, karena manajemen akan berusaha mengakumulasikan keuntungan kedalam laba ditahan dan berguna untuk pendanaan internnya

d. Earning Predictability. Jika keuntungan berfluktuasi maka dividend tidak dapat bergantung semata-mata dari keuntungan tersebut, sehingga diperlukan adanya trend keuntungan yang stabil untuk menentukan porsi dividen yang direncanakan. 
e. Ownership Control: Jika perusahaan memutuskan untuk membayarkan dividend yang tinggi, hal ini akan menyebabkan laba ditahan tidak cukup untuk membiayai investasi saham barunya. Salah satu cara untuk mengatasi hal ini adalah perusahaan mengorbitkan saham baru untuk mencukupi dananya. Keputusan ini menimbulkan control dari pemegang saham perusahaan lama semakin berkurang. Tentunya hal ini tidak diinginkan oleh para pemegang saham, sehingga mereka akan lebih menyukai dengan tidak memperoleh dividend.

f. Inflation: Inflasi yang tinggi akan menyebabkan kemampuan perusahaan tidak dapat mencukupi untuk melakukan investasi yang baru, sehingga perusahaan akan melakukan akumulasi dananya kedalam laba ditahan. Hal ini akan berdampak pada penurunan terhadap pembayaran dividend, atau bahkan tidak melakukan pembayaran dividend.

\section{Hipotesis}

1. Diduga terdapat model yang paling fit atau yang paling tepat untuk merumuskan hubungan dan pengaruh secara simultan atas variabel-variabel : Assets (diwakili posisi kas/cash position $=\mathrm{X} 1$, potensi pertumbuhan/growth potential $=\mathrm{X} 2$, ukuran perusahaan $/$ firm size $=\mathrm{X} 3$, perbandingan antara kewajiban dengan modal/debt to equity ratio $=\mathrm{X} 4$ ); Equity (ukuran perusahaan/firm size $=\mathrm{X} 3$, debt to equity ratio $=\mathrm{X} 4$ dan kepemilikan/Holding $=\mathrm{X} 6$ ); Earnings (keuntungan/profitability $=\mathrm{X5}$, kepemilikan/holding $=\mathrm{X6}$ ) terhadap kebijakan dividend payout ratio (DPR) pada perusahaan yang go public di Bursa Efek J akarta.

2. Diduga ada pengaruh assets, equity dan earnings secara bersama-sama (simultan) terhadap kebijakan dividend payout ratio (DPR) pada perusahaan yang go public di Bursa Efek Jakarta.

3. Diduga ada pengaruh assets, equity dan earnings secara sendiri-sendiri (partial) terhadap kebijakan devidend payout ratio (DPR) pada perusahaan yang go public di Bursa Efek Jakarta.

\section{E. Metode Penelitian}

\section{Populasi dan Sampel}

Populasi dalam penelitian ini adalah seluruh perusahaan yang terdaftar pada PT Bursa Efek Jakarta sampai dengan 31 Maret 2006. 
Sampel dalam penelitian ini sebanyak 94 observasi atau perusahaan. Sedangkan teknik pengambilan sampel dengan menggunakan metode purpose random sampling, dengan kriteria:

a. Perusahaan terdaftar di PT Bursa Efek Jakarta sampai dengan 31 Maret 2006.

b. Data perusahaan lengkap dengan faktor-faktor atau variabel yang akan diteliti dalam penelitian ini

c. Dividend Payout Ratio (DPR) lebih kecil atau sama dengan satu, karena untuk menghindari gulung tikar bagi emiten.

\section{Variabel Penelitian}

a. Cash Position (X1)

b. Growth Potential (X2)

c. Firm Size (X3)

d. Debt to Equity Ratio (X4)

e. Profitability (X5)

f. Holding (X6).

g. Dividend Payout Ratio (Y)

h. Assets (Y1)

i. Equity (Y2)

j. Earning atau keuntungan (Y3)

\section{Jenis dan Sumber Data}

Jenis data yang digunakan dalam penelitian ini adalah data sekunder yang meliputi laporan keuangan tahunan perusahaan dan laporan kegiatan perdagangan saham. Sumber data yang digunakan diperoleh dari :
a. Database harga saham harian PT Bursa Efek Jakarta
b. Pojok PT Bursa Efek Jakarta Universitas Islam Indonesia Yogyakarta
c. Indonesian Capital Market Directory
d. Jakarta Stock Exchange (JSX) Fact Book
e. Jakarta Stock Exchange (J SX) Monthly Statistic
f. Jurnal Pasar Modal
g. Harian Bisnis Indonesia
h. Laporan Emiten
i. Sumber lainnya yang terkait dengan penelitian ini 


\section{Pengolahan dan Analisis data}

\section{a. Pengolahan Data}

Alat analisis dalam penelitian ini menggunakan regresi berganda maka sebelum dilakukan perhitungan dengan analisis regresi berganda perlu dilakukan uji asumsi atau uji prasyarat. Untuk uji asumsi ini dilakukan tiga macam uji yaitu: (1) Uji Normalitas; (2) Uji Heteroskedastisitas; dan (3) Uji Multikolinearity. Untuk mengetahui hasil uji asumsi ini dilakukan dengan bantuan program SPSS.

\section{b. Analisis Data}

Pengujian dilakukan dengan menggunakan Regresi Bertahap atau Multistage Regression dan Analisis J alur (Path Analysis).

Langkah dalam pemasukan input meliputi sebanyak 94 sampel size yang terdiri dari 10 (sepuluh) variabel, $\mathrm{X}_{1}=$ Posisi kas ( Cash Position), $\mathrm{X}_{2}=$ Potensi pertumbuhan (Growth potentia), $\mathrm{X}_{3}=$ Size perusahaan (firm Size),

$\mathrm{X}_{4}=$ Rasio hutang dan modal (debt to equity ratio), $\mathrm{X}_{5}=$ Profitabilitas ( profitability), $\mathrm{X}_{6}=$ Holding, dan $\mathrm{Y}=$ Dividend Payout Ratio $(D P R) ; \mathrm{Y} 1=$ Asset, Y2 = Equity, $\mathrm{Y}_{3}=$ Earning

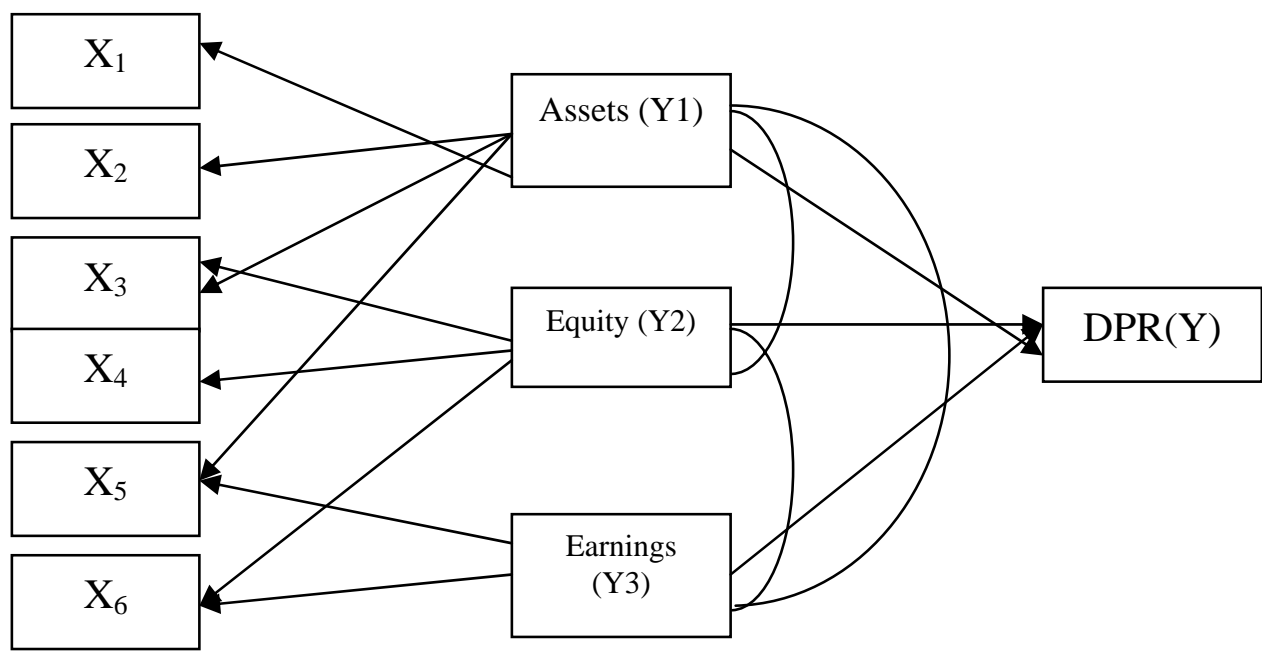


Untuk mencari model terbaik atau fit (Hipotesis 1), dilakukan dengan Regresi Bertahap dan Analisis J alur.

Tahap 1: $\quad \mathrm{Y} 1=\mathrm{bo}+\mathrm{b} 1 . \mathrm{X} 1+\mathrm{b} 2 . \mathrm{X} 2+\mathrm{b} 3 . \mathrm{X} 3+\mathrm{b} 4 . \mathrm{X} 4+\mathrm{e}$

Tahap 2: $\quad Y 2=b 0+b 3 . X 3+b 4 . X 4+b 6 . X 6+e$

Tahap 3: $\quad Y 3=b 0+b 5 . X 5+b 6 . X 6+e$

Tahap 4: $\quad Y=$ bo $+b 1 . Y 1+b 2 . Y 2+b 3 . Y 3+e$

Untuk menguji hipotesis 2 dan hipotesis 3 digunakan Uji F dan Uji t. Uji F digunakan untuk melihat pengaruh secara bersama-sama dari semua variabel bebasnya terhadap variabel terikatnya, sedangkan Uji t untuk menguji secara sendirisendiri (parsial) pengaruh semua variabel bebasnya terhadap variabel terikatnya.

\section{G. Hasil Penelitian Dan Pembahasan}

\section{Data Penelitian}

Dari hasil pengambilan sampel sebanyak 94 perusahaan yang go public di Bursa Efek Jakarta diperoleh gambaran nilai rata-rata dan standar deviasi dari masing-masing variabel yang diamati sebagai berikut:

Tabel 5.1. Nilai Rata-rata dan Nilai Standar Deviasi Variabel

\begin{tabular}{|c|l|l|l|}
\hline No & \multicolumn{1}{|c|}{ Nama Variabel } & \multicolumn{1}{|c|}{ Mean } & \multicolumn{1}{c|}{ Standar Deviasi } \\
\hline 1 & X1 (Posisi Kas) & 1781.51333 & 1983.73635 \\
\hline 2 & X2 (Pertumbuhan) & 7.3789 & 1.76796 \\
\hline 3 & X3 (Size) & 2.05189 & 2.62736 \\
\hline 4 & X4 (DER) & 1.6613 & 2.14427 \\
\hline 5 & X5 (Profitabilitas) & 0.08039 & 0.06455 \\
\hline 6 & X6 (Holding/Kepemilikan) & 4.73 & 2.201 \\
\hline 7 & Y1 (Assets) & 9654.63 & 27021.694 \\
\hline 8 & Y2 (Equity) & 2399.14 & 4726.675 \\
\hline 9 & Y3 (Earning) & 485.90 & 1338.687 \\
\hline 10 & Y (DPR) & 0.30791 & 0.201877 \\
\hline
\end{tabular}

Sumber: Data diolah

Dari tabel 5.1 di atas dapat diperoleh gambaran bahwa rata-rata tingkat pertumbuhan perusahaan yang go public di Bursa Efek Jakarta sebesar 7.3789; dengan tingkat profitabilitas sebesar 0.8039 atau $8.039 \%$ dan rata-rata Dividend Payout Ratio (DPR) sebesar 0.30791. 


\section{a. Pengujian Prasyarat Regresi (Asumsi Klasik)}

Dari 4 (empat) model Regresi yang diajukan dalam penelitian ini yaitu:

1). Model Regresi Tahap 1 dengan Variabel bebas Posisi Kas (X1), Pertumbuhan (X2), Size (X3), DER (X4) dan Variabel terikatnya Assets (Y1) dari hasil Uji Normalitas diketahui bahwa sebaran titik-titik masih berada di sekitar diagonal utama atau dengan kata lain dapat dikatakan bahwa model berdistribusi normal. Hasil uji heteroskedastisitas juga menunjukkan sebaran titik-titik tersebar acak, sehingga model ini dapat dikatakan tidak terjadi heteroskedastisitas. Sedangkan dari hasil uji multikolinearity dengan menggunakan nilai VIF (Variance Influence Factors) diketahui bahwa semua nilai jauh di bawah 10, sehingga dapat dikatakan model bebas multikol. Untuk lebih jelasnya dapat dilihat di lampiran 2.

2). Model Regresi Tahap 2 dengan Variabel Size (X3), DER (X4), Holding (X6) dan Variabel terikatnya Equity (Y2) dari hasil Uji Normalitas diketahui bahwa sebaran titik-titik masih berada di sekitar diagonal utama atau dengan kata lain dapat dikatakan bahwa model berdistribusi normal. Hasil uji heteroskedastisitas juga menunjukkan sebaran titik-titik tersebar acak, sehingga model ini dapat dikatakan tidak terjadi heteroskedastisitas. Sedangkan dari hasil uji multikolinearity dengan menggunakan nilai VIF (Variance Influence Factors) diketahui bahwa semua nilai jauh di bawah 10, sehingga dapat dikatakan model bebas multikol. Untuk lebih jelasnya dapat dilihat di lampiran 2.

3). Model Regresi Tahap 3 dengan Variabel bebas Profit (X5), Holding (X6) dan Variabel terikatnya Earning (Y3) dari hasil Uji Normalitas diketahui bahwa sebaran titik-titik masih berada di sekitar diagonal utama atau dengan kata lain dapat dikatakan bahwa model berdistribusi normal. Hasil uji heteroskedastisitas juga menunjukkan sebaran titik-titik tersebar acak, sehingga model ini dapat dikatakan tidak terjadi heteroskedastisitas. Sedangkan dari hasil uji multikolinearity dengan menggunakan nilai VIF (Variance Influence Factors) diketahui bahwa semua nilai jauh di bawah 10, sehingga dapat dikatakan model bebas multikol. Untuk lebih jelasnya dapat dilihat di lampiran 2.

4). Model Regresi Tahap 4 dengan Variabel bebas Assets (Y1), Equity (Y2), Earning (Y3) dan Variabel terikatnya DPR (Y) dari hasil Uji Normalitas diketahui bahwa sebaran titik-titik masih berada di sekitar diagonal utama atau dengan kata lain dapat dikatakan bahwa model berdistribusi normal. Hasil uji heteroskedastisitas juga menunjukkan sebaran titik-titik tersebar 
acak, sehingga model ini dapat dikatakan tidak terjadi heteroskedastisitas. Sedangkan dari hasil uji multikolinearity dengan menggunakan nilai VIF (Variance Influence Factors) diketahui bahwa semua nilai jauh di bawah 10 , sehingga dapat dikatakan model bebas multikol.

\section{b. Pengujian Hipotesis}

1). Pengujian Hipotesis 1, memilih model:

a). Model Regresi Tahap 1 dengan Variabel bebas Posisi Kas (X1), Pertumbuhan (X2), Size (X3), DER (X4) dan Variabel terikatnya Assets (Y1), diperoleh $\mathrm{F}$ hitung 36,521 dan sig $0 \%$ (Selengkapnya dapat dilihat pada Lampiran 2). Persamaan dalam Z sbb:

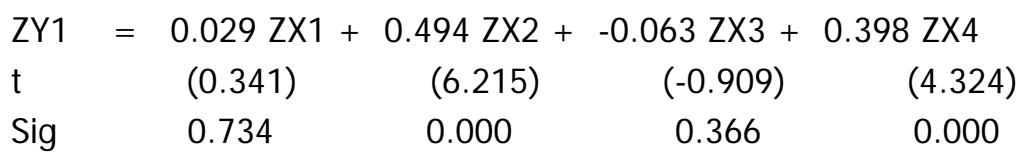

R Square: 0.621

Dari pengujian Tahap 1, dapat disimpulkan :

(1) Terdapat pengaruh langsung Pertumbuhan (X2) terhadap Assets (Y1) sebesar $=0.494$

(2) Terdapat pengaruh langsung DER (X4) terhadap Assets (Y1) sebesar $=0.398$

b). Model Regresi Tahap 2 dengan Variabel Size (X3), DER (X4), Holding (X6) dan Variabel terikatnya Equity (Y2), diperoleh F hitung 4.702 dan sig 0.004. (Selengkapnya dapat dilihat pada Lampiran 2). Persamaan dalam Z sbb:

$\begin{array}{lccc}Z Y 2 & 0.198 Z X 3 & + & 0.324 Z X 4 \\ t & (1.963) & (3.290) & 0.078 Z X 6 \\ \text { Sig } & 0.050 & 0.001 & (0.786) \\ R & 0.434\end{array}$

R Square: 0.135

Dari pengujian Tahap 2, dapat disimpulkan :

(1) Terdapat pengaruh langsung Size (X3) terhadap Equity (Y2) sebesar $=0.198$

(2) Terdapat pengaruh langsung DER (X4) terhadap Equity (Y2) sebesar $=0.324$

c). Model Regresi Tahap 3 dengan Variabel bebas Profit (X5), Holding (X6) dan Variabel terikatnya Earning (Y3), diperoleh F hitung 2.590 dan 
sig 0.081. (Selengkapnya dapat dilihat pada Lampiran 2). Persamaan dalam Z sbb:

$\begin{array}{llr}\mathrm{ZY3}= & 0.215 \mathrm{ZX5}+ & -0,063 \mathrm{ZX6} \\ \mathrm{t} & (2.085) & (-0.613) \\ \mathrm{Sig} & 0.040 & 0.541\end{array}$

R Square $=0.054$

Dari pengujian Tahap 3, dapat disimpulkan :

(1) Terdapat pengaruh langsung Profit (X5) terhadap Earning (Y3) sebesar $=0.215$

d). Model Regresi Tahap 4 dengan Variabel bebas Assets (Y1), Equity $(\mathrm{Y} 2)$, Earning $(\mathrm{Y} 3)$ dan Variabel terikatnya DPR $(\mathrm{Y})$, diperoleh $\mathrm{F}$ hitung sebesar 3.911 dan sig 0.011. (Selengkapnya dapat dilihat pada Lampiran 2). Persamaan dalam $Z \mathrm{sbb}$ :

\begin{tabular}{|c|c|c|c|}
\hline ZY & $\begin{array}{c}-0.085 \mathrm{ZY} 1+ \\
(-0.545)\end{array}$ & $\begin{array}{r}0.677 \mathrm{ZY} 2 \\
(2.728)\end{array}$ & $\begin{array}{r}-0.387 \text { ZY3 } \\
(-1.955)\end{array}$ \\
\hline & 0.578 & 0.008 & 0.054 \\
\hline
\end{tabular}

R Square: 0.115

Dari pengujian Tahap 4, dapat disimpulkan:

J ika menggunakan alpha $10 \%$ :

(1) Terdapat pengaruh langsung Equity (Y2) terhadap DPR (Y) sebesar $=0.677$

(2) Terdapat pengaruh langsung Earning (Y3) terhadap DPR (Y) sebesar $=-0.387$

J ika menggunakan alpha 5\%:

(1) Terdapat pengaruh langsung Equity (Y2) terhadap DPR (Y) sebesar $=0.677$

Dari pengujian Regresi Tahap 1 sampai Tahap 4, dapat disimpulkan bahwa model terbaik untuk menjelaskan perilaku DPR (Y) adalah menggunakan Variabel Size (X3); Variabel DER (X4) yang mempunyai pengaruh langsung dan signifikan terhadap Equity (Y2), tetapi mempunyai pengaruh tidak langsung terhadap DPR (Y).

2). Pengujian Hipotesis 2,

Bahwa diduga ada pengaruh secara bersama-sama variabel Asset ( $Y 1)$; Equity (Y2); dan Earning (Y3) terhadap DPR (Y); dengan menggunakan Uji F diketahui bahwa $\mathrm{F}$ hitung sebesar 3.911 pada signifikansi 1.1\%. Karena taraf 
signifikansi $1.1 \%$ < alpha 5\%, maka dapat disimpulkan bahwa hipotesis yang menyatakan ada pengaruh signifikan secara bersama-sama variabel Asset, Equity dan Earning terhadap Kebijakan Dividend Payout Ratio pada perusahaan yang go public di Bursa Efek Jakarta diterima.

3). Pengujian Hipotesis 3,

Bahwa diduga ada pengaruh secara sendiri-sendiri (partial) antara variabel Asset (Y1); Equity (Y2); dan Earning (Y3) terhadap DPR (Y); dengan menggunakan Uji t diketahui bahwa t hitung untuk Variabel Asset 0.545 signifikansi $58.7 \%$ karena taraf signifikansi $58.75 \%$ > alpha 5\%, maka dapat disimpulkan bahwa tidak ada pengaruh signifikan antara variabel Asset secara sendirian terhadap Kebijakan Dividend Payout Ratio pada perusahaan yang go public di Bursa Efek Jakarta. Hasil uji t diketahui bahwa t hitung untuk Variabel Equity 2.728 signifikansi $0.8 \%$ karena taraf signifikansi $0.8 \%$ $<$ alpha 5\%, maka dapat disimpulkan bahwa ada pengaruh signifikan antara variabel Equity secara sendirian terhadap Kebijakan Dividend Payout Ratio pada perusahaan yang go public di Bursa Efek Jakarta. Hasil uji t diketahui bahwa t hitung untuk Variabel Earning -1.955 signifikansi 5.4\% karena taraf signifikansi $5.4 \%>$ alpha 5\%, maka dapat disimpulkan bahwa tidak ada pengaruh signifikan antara variabel Earning secara sendirian terhadap Kebijakan Dividend Payout Ratio pada perusahaan yang go public di Bursa Efek Jakarta.

\section{Pembahasan}

Dari hasil analisis regresi berganda yang dilakukan secara bertahap (Multistage Regression) dapat dijelaskan bahwa dari 6 (enam) variabel yang diperkirakan mempunyai pengaruh tidak langsung terhadap Dividend Payout Ratio (DPR) ternyata hanya 2 (dua) variabel yaitu Variabel Ukuran Perusahaan (Size = X3) dan Variabel Debt to Equity Ratio (DER = X4). Variabel Size (X3) dan DER (X4) mampu menjelaskan perilaku variabel DPR melalui variabel intervening atau variabel antara Equity (Y2). Sedangkan variabel Pertumbuhan (X2) sebenarnya mempunyai pengaruh yang signifikan terhadap Asset (Y1), tetapi Asset pengaruhnya tidak signifikan terhadap DPR (Y). Demikian juga variabel Profit (X5) mempunyai pengaruh yang signifikan terhadap Earning (Y3), tetapi Earning (Y3) pengaruhnya tidak signifikan terhadap DPR (Y). Hal ini bisa dimaklumi karena sebenarnya ada banyak faktor yang mempengaruhi kebijakan dividen dalam suatu 
perusahaan dan banyak faktor tersebut saling berinteraksi (terjadi interdependensi) satu sama lain dan juga antara satu jenis perusahaan dengan perusahaan lain juga ada perbedaan-perbedaan pertimbangan.oleh kerana itu sangatlah sulit untuk memperoleh suatu model yang secara general atau umum mampu menjelaskan perilaku perusahaan dalam kebijakan dividend payout rationya.

Di sisi lain, pada regresi model ke dua ternyata untuk menjelaskan DPR melalui Asset, Equity dan Earning, ternyata secara model (dengan Uji F) signifikan tetapi secara parsial hanya variabel Equity saja yang signifikan. Dan model inipun hanya mampu menjelaskan perilaku variabel terikatnya sebesar $11,5 \%$. Melihat $\mathrm{R}$ square yang masih sedemikian rendah tentunya model ini masih jauh dari sempurna, oleh karena itu penelitian-penelitian mendatang diharapkan mampu menambah dan memilih varaibel-variabel baru yang sekiranya mampu meningkatkan $\mathrm{R}$ square.

\section{H. Kesimpulan}

Dari uraian di atas dapat ditarik kesimpulan sebagai berikut:

1. Hasil pengujian dengan Regresi Tahap 1 sampai Tahap 4, dapat disimpulkan bahwa model terbaik untuk menjelaskan perilaku DPR $(Y)$ adalah menggunakan Variabel Size (X3); Variabel DER (X4) yang mempunyai pengaruh langsung dan signifikan terhadap Equity (Y2), tetapi mempunyai pengaruh tidak langsung terhadap DPR (Y). Sedangkan variabel Pertumbuhan (X2) sebenarnya mempunyai pengaruh yang signifikan terhadap Asset (Y1), tetapi Asset pengaruhnya tidak signifikan terhadap DPR (Y). Demikian juga variabel Profit (X5) mempunyai pengaruh yang signifikan terhadap Earning (Y3), tetapi Earning (Y3) pengaruhnya tidak signifikan terhadap DPR (Y).

2. Ada pengaruh secara bersama-sama variabel Asset (Y1); Equity (Y2); dan Earning $(\mathrm{Y} 3)$ terhadap DPR $(\mathrm{Y})$; dengan $\mathrm{F}$ hitung sebesar 3.911 pada signifikansi $1.1 \%$. Karena taraf signifikansi $1.1 \%$ < alpha 5\%, maka dapat disimpulkan bahwa hipotesis yang menyatakan ada pengaruh signifikan secara bersama-sama variabel Asset, Equity dan Earning terhadap Kebijakan Dividend Payout Ratio pada perusahaan yang go public di Bursa Efek J akarta diterima

3. Secara sendiri-sendiri (partial) diantara variabel Asset (Y1); Equity (Y2); dan Earning $(\mathrm{Y} 3)$ terhadap $D P R(\mathrm{Y})$; ternyata hasil uji t hanya Variabel Equity dengan t hitung $=2.728$ signifikansi $0.8 \%$ karena taraf signifikansi $0.8 \%<$ alpha $5 \%$, maka dapat disimpulkan bahwa ada pengaruh signifikan antara variabel Equity secara sendirian terhadap Kebijakan Dividend Payout Ratio pada perusahaan yang go public di Bursa Efek Jakarta. 


\section{Daftar Pustaka}

Alexander, Gordon.,William F. Sharpe., dan Jeffery V. Beily., 1993, "Fundamentals of Investments," Secon Edition, Prentice-Hall Inc.

Alli, Kasim L,, A. Qayyum Khan, dan Gabriel G. Ramirez., 1993, "Determionant of Corporate Dividend Policy: A Factor Analysis," The Financial Review, Volume 24, No. 4, Nopember, 523-547

Baker K., G. Farelly, dan R. Edelman, 1985, "A Survay of Management Views on Duvudend Policy," Fianancial Management, Autumm, 78-84.

Brennan, M., dan A. Thakor., 1990," Shareholder preferences and dividend PolicY." Jurnal of Finance, September, 993-1018

Chang R.P., dan S.G. Rhee.,1990, "Texas and Dividends: The Impact of personal Taxes on Corporate Dividend Policy and Capitol Structure Decisions," Financial Management, Summer, 21-31.

De Angelo, H., dan R. Masulis, 1980," Leverage and Dividend Irrerelevancy Under Corporate and personal Taxation." Journal of Finance, June, 453-464.

Fama, E., 1974, "The Empirical Relationships Between Dividend and Investment Decision on Firms." American Economic Review, J une, 304-318.

Hair, Joseph F., R.E. Andersen., R. L. Tatham., dan W. C. Black., 1998,"Multivariate Data Analysis-With Reading," Fith Editian, Prentice-Hall Inc.

John, K., dan J. Williams., 1985,"Dividend Dilution and tewas: A Signaling Equilibrium." J ournal of Finance, September, 1053-1069.

Levy, H., dan M.Sarnat., 1990,"Capital Investmen and Financial decision,"Fourth Edition, Prentice-Hall Inc.

Lintner, John., 1956," Distribution of Incomes of Corporatiopn ot Among Dividends, Retained Earnings and Texas, The American Riview, May, 97-113

Miller, M., dan F. Modigliani, 19861,"Dividend Policy, growth and The Valuation of Shares," journal of Business, October, 433-443

Myers, S., dan S. Majluf., 1984,"Corporate Financing and Investment Decision When Firms Have Information that Investors Do Not Have," Journal of Financial Economics, J une, 187-221

Rozeff, M., 1982," Beta and Agency Cost as Determinants of payout Ratio." Journal of Financial Research, Fall, 249-259.

Setyawan, Widyantoro., 1995," Analisis Beberapa Faktor Yang Berpengaruh Terhadap Kebijakan Dividend Pada Badan Usaha Milik Negara Bentuk Pesero." Tesis. Program Pascasarjana Universitas Gajahmada.

SPSS., 1999," Statistical Package for the Social Sciense Base 9.01 Application Guide." SPSS Inc.

Stanley, B. B., dan A. H. Geoffrey., 1987," Foundation of Financial management," Fopurth Management, Richard D. Irwin, Homewood.

Turnovsky, Stephen, Y., 1967,"The Allocation of Corporate Profits Between Dividend and Retained Earnings," The Riview of Economics and Statistics, November.

Van Horn, James C., 1986," Fundamentals of Financial Mangement," Seventh Edition, Prentice-Hall Inc. 